\title{
MODEL PENUNJANG KEPUTUSAN JADWAL PRODUKSI JUS BUAH SEGAR
}

\author{
IFFAN MAFLAHAH', MACHFUD ${ }^{2}$, DAN FAQIH UDIN ${ }^{2}$ \\ ${ }^{1}$ Jurusan Teknologi Industri Pertanian, Universitas Trunojoyo Madura \\ ${ }^{2}$ Jurusan Teknologi Industri Pertanian, Institut Pertanian Bogor \\ E-mail: iffanmaflahah@trunojoyo.ac.id
}

\begin{abstract}
ABSTRAK
Perencanaan dan pengendalian produksi merupakan faktor penting untuk mendapatkan efisiensi melalui pengelolaan persediaan pasokan bahan baku buah segar, perencanaan produksi dan jadwal produksi. Penelitian ini bertujuan untuk mengembangkan model perencanaan produksi agregat dan jadwal induk produksi jus berbahan baku buah segar yang memperhatikan karakteristik buah yang mudah rusak. Terdapat beberapa metode yang digunakan yaitu autoregressive integrated moving average (ARIMA) untuk prediksi pasokan bahan baku dan penjualan jus, model matematis untuk persediaan bahan baku buah segar yang layak diproduksi, programa linier untuk perencanaan produksi dan jadwal induk perspektif untuk mengembangkan jadwal induk produksi. Penelitian ini menghasilkan sistem penunjang keputusan yang diberi nama RP JUS. Hasil analisis terhadap laju kerusakan bahan baku menunjukkan bahwa laju kerusakan buah mengikuti distribusi eksponensial. Hasil analisis terhadap laju kerusakan bahan baku menunjukkan bahwa laju kerusakan buah mengikuti distribusi eksponensial. Model penunjang keputusan jadwal produksi jus buah segar dapat langsung diaplikasikan pada industri pengolahan yang menggunakan bahan baku buah segar.
\end{abstract}

Kata kunci: jus, perencanaan produksi agregat, jadwal produksi induk, model penunjang keputusan

\begin{abstract}
Planning and production control are important factors to determine the efficiency derived through proper management of raw material supply of fresh fruits, production planning and master production schedule. This research aimed to develop the aggregate production planning model, and master production schedule model for juice production from fresh fruit, while also considered the perishability of the fresh fruit. There were several methods applied in the works, namely autoregressive integrated moving average (ARIMA) for forecasting of raw material product sale, mathematical model for raw material supply, linear programming for production planning and prospective production scheduling to develop master production schedule. This research developed software for decision support system called RP_JUS. The results showed that all raw material damage was distributed exponentially. Decision Support Model of Production Schedule for Fresh Fruit Juice can be applied to the processing indudtries that use fresh fruit.
\end{abstract}

Key words: juice, aggregate production planning, master production schedule, decision support model

\section{PENDAHULUAN}

Perencanaan dan pengendalian produksi sangat dibutuhkan untuk memenuhi kebutuhan konsumen. Perencanaan produksi merupakan tahapan awal dalam menyusun jadwal produksi. Kegiatan produksi jus buah sangat ditentukan oleh ketersediaan bahan baku buah segar dan jumlah permintaan. Bahan baku sebagai masukan akan diproses untuk menghasilkan produk. Keterbatasan kapasitas, laju pasokan bahan baku secara musiman dan fluktuasi permintaan akan memicu konflik dalam kegiatan perencanaan produksi. Hal ini menjadi isu penting dalam peningkatan efisiensi kegiatan produksi pada agro industri pengolahan buah segar.
Pahl et al. (2008) mengatakan kendala utama dalam memproduksi suatu barang adalah umur simpan (lifetime), sehingga perusahaan harus memperhatikan hal tersebut dalam produksi dan distribusinya. Aliran bahan baku dalam rantai pasokan memengaruhi kerusakan pada setiap segmen. Masalah kekurangan dan kelangkaan pasokan bahan baku merupakan masalah utama pada industri pengolahan hasil pertanian. Pasokan bahan baku buah segar mempunyai karakteristik musiman, mudah rusak, beragam, dan bulky. Pasokan bahan baku buah bersifat musiman, sedangkan permintaan konsumen terhadapjus buah terjadi sepanjang waktu. Permasalahannya adalah bagaimana merencanakan 
dan mengendalikan produksi jus dari buah segar dengan memperhatikan laju kerusakan dari bahan baku. Perencanaan dan pengendalian produksi akan berperan dengan memperhatikan karakteristik tersebut melalui pengelolaan persediaan bahan baku, perencanaan produksi dan penjadwalan. Tsobune et al. (1986) secara khusus mengembangkan model produksi untuk produk agro industri dengan komponen sistem produksi terdiri dari persediaan bahan baku, proses barang setengah jadi, proses akhir produk, persediaan barang setengah jadi, dan persediaan produk akhir. Model ini sangat baik karena mampu merepresentasikan secara umum karakteristik agro industri dengan fokus pada sifat perishable komoditas.

Pengelolaan persediaan bertujuan minimisasi biaya dan kerusakan buah segar, perencanaan produksi dimaksudkan untuk menjamin kelancaran proses produksi dan jadwal induk produksi ditujukan untuk menjaga kualitas dan tingkat persediaan yang minimum.Penelitian ini bertujuan menghasilkan suatu perencanaan produksi agregat, model jadwal induk produksi, model ketersediaan bahan baku dan model sistem penunjang keputusan jadwal produksi jus buah segar. Model jadwal produksi jus berbahan baku buah segar dapat dijadikan sebagai alat penunjang keputusan bagi perusahaan dalam membantu menyusun rencana produksi berdasarkan prakiraan permintaan.

\section{METODE}

Metode-metode yang digunakan adalah autoregressive integrated moving average (ARIMA) untuk prakiraan jumlah pasokan bahan baku buah segar dan prakiraan jumlah penjualan jus, permodelan matematika untuk ketersediaan bahan baku buah yang layak diproduksi dengan mempertimbangkan laju kerusakan bahan baku buah, dan programa linier untuk optimasi perencanaan produksi agregat. Sedangkan permodelan untuk jadwal induk produksi mengunakan teknik penjadwalan produksi perspektif.

Asmundsson et al. (2002) menyatakan bahwa pemrograman model matematika digunakan untuk perencanaan produksi agregat, model antrian dan penggunaan model simulasi untuk analisis performa. Techawiboonwong and Yenradee (2002) memanfaatkan spreadsheet solver sebagai sistem penunjang keputusan dalam perencanaan produksi. Model ini memang digunakan khususnya untuk industri manufaktur. Sedangkan Filho et al. (2006) mengembangkan model perencanaa agregat dengan obyektif majemuk yang khusus untuk industri manufaktur. Model ini tidak bisa diterapkan untuk perencanaan produksi di agro industri karena tidak memasukkan sifat perishable dari bahan baku atau produk yang dihasilkan.

Model jadwal produksi jus berbahan baku buah segar menggunakan beberapa asumsi untuk mendukung penyusunan model. Pembuatan model perencanaan produksi agregat dan jadwal induk produksi jus ini digunakan beberapa asumsi, yaitu 1) model yang dikembangkan berdasarkan parameter prakiraan jumlah penjualan periode, prakiraan jumlah pasokan bahan baku buah, umur simpan buah, kemampuan produksi, ketersediaan sumberdaya dan jumlah persediaan, 2) proses produksi berjalan lancar, 3) harga bahan baku tidak berubah, 4) sumberdaya dan fasilitas yang digunakan selama proses produksi tetap selama proses perencanaan, 5) jumlah permintaan bulanan didisagregasi menjadi permintaan mingguan dengan asumsi pada minggu pertama sejumlah 10 persen, minggu kedua 30 persen, minggu ketiga 40 persen dan minggu keempat 20 persen dari prakiraan jumlah penjualan jus. Buah segar yang dipasok adalah buah jambu, sirsak, nenas, apel dan strawberi. Horison waktu perencanaan dibuat selama 12 periode (bulan) ke depan.

\section{HASIL DAN PEMBAHASAN}

Tahapan analisis kebutuhan sistem merupakan tahap awal dari permulaan pengkajian suatu sistem. Analisis ini akan dinyatakan dalam kebutuhan-kebutuhan yang ada, kemudian dilakukan pengembangan kebutuhan-kebutuhan yang dideskripsikan. Analisis kebutuhan yang berpengaruh dalam model jadwal produksi jus berbahan baku buah segar adalah jumlah pemesanan bahan baku, penggunaan bahan baku yang optimal, ketepatan datangnya pasokan bahan baku dan tercapainya target produksi. Selain itu, dalam penyusunan model dibutuhkan ketersediaan produk jus dalam waktu dan jumlah yang sesuai, kualitas jus yang baik, kelancaran proses produksi, meminimumkan biaya operasional, memperoleh keuntungan yang maksimum, optimasi penggunaan sumberdaya, mampu memenuhi permintaan pasar dan resiko kegagalan investasi kecil.

Identifikasi sistem menentukan batasan sistem dan ruang lingkup penelaahan penelitian dan bertujuan untuk memberikan gambaran terhadap sistem yang dikaji dalam bentuk diagram. Identifikasi sistem ditunjukkan dengan diagram input output (black box diagram) atau diagram masukan keluaran. Diagram masukan keluaran model jadwal produksi jus berbahan baku buah segar dapat dilihat pada Gambar 1. 


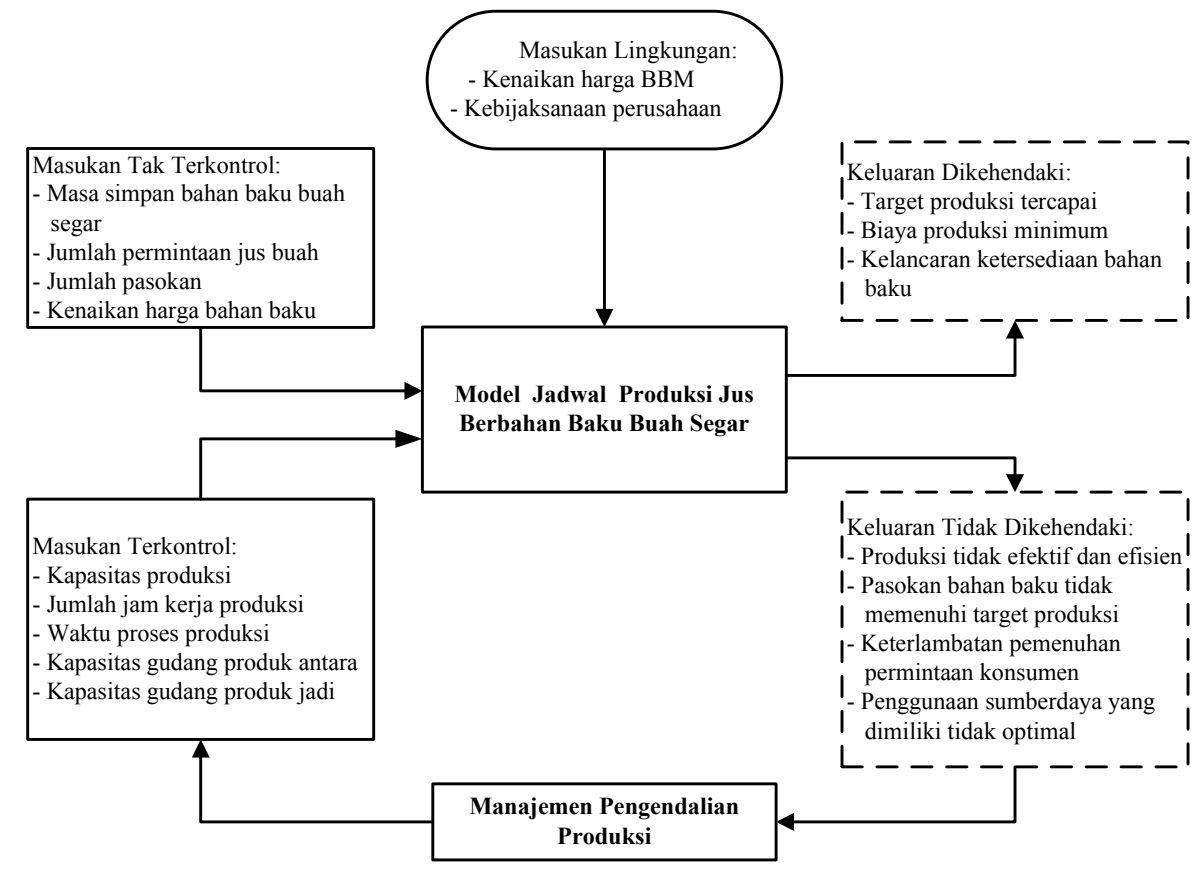

Gambar 1. Diagram Masukan Keluaran Model Jadwal Produksi Jus Berbahan Baku Buah Segar

Keluaran yang dikehendaki merupakan pemenuhan kebutuhan pada masing-masing stakeholder pada identifikasi kebutuhan atau tujuan yang ingin dicapai dari pengembangan model. Sedangkan keluaran yang tidak dikehendaki merupakan hasil samping dari sistem yang merupakan dampak yang ditimbulkan dari sistem tersebut, jika hal ini yang timbul maka dapat ditinjau kembali input yang terkendali melalui kontrol manajemen. Keluaran yang dikehendaki adalah target produksi tercapai, biaya produksi minimum dan kelancaran kesediaan bahan baku. Sedangkan hasil samping dari sistem adalah produksi yang tidak efisien dan efektif, pasokan bahan baku tidak memenuhi target produksi, keterlambatan pemenuhan permintaan konsumen serta penggunaan sumberdaya yang dimiliki tidak optimal. Keluaran model yang tidak dikehendaki akan dikendalikan oleh manajemen pengendalian produksi dalam sebuah masukan terkontrol agar keluaran yang tidak dikehendaki tidak terjadi.

Masukan yang membatasi pengembangan model adalah kapasitas produksi, jumlah jam produksi, waktu proses produksi, kapasitas gudang produk antara dan kapasitas gudang produk jadi. Sedangkan masukan yang tidak dapat dikendalikan oleh model adalah masa simpan bahan baku buah segar, jumlah permintaan jus buah, jumlah pasokan dan kenaikan harga bahan baku. Masukan lingkungan berpengaruh terhadap pengembangan model yaitu kenaikan harga BBM dan kebijakan perusahaan terdapat kelangsungan proses produksi.

\section{Model Prakiraan Pasokan Bahan Baku Buah Segar dan Prakiraan Penjualan Jus}

Prakiraan pasokan bahan baku buah segar menggunakan data masa lalu jumlah pasokan bahan baku buah masing-masing jenis buah setiap bulannya. Sedangkan prakiraan penjualan jus menggunakan data masa lalu jumlah penjualan masing-masing jus.Model identifikasi ordo ARIMA adalah ARIMA $(p, d, q)(P, D, Q)^{s}$ untuk data pasokan bahan baku buah segar. Selain itu dapat pula ditunjukkan dengan persamaan yang dinyatakan dengan $\mathrm{X}_{\mathrm{t}}{ }^{\mathrm{j}}$. Jika $\mathrm{X}_{\mathrm{t}}{ }^{\mathrm{j}}$ merupakan prakiraan jumlah pasokan periode ke-t jenis buah $j, \mathrm{e}_{t}$ adalah error periode ke- $t, \Theta_{1}$ adalah koefisien moving average (MA), $\emptyset_{1}$ adalah koefisien autoregressive (AR) dan $\Phi_{1}$ adalah koefisien seasonal autoregressive (SAR).

Model prakiraan pasokan buah jambu $(0,1$, 1) $(0,1,0)^{12}$, buah sirsak $(0,0,1)(1,1,0)^{12}$, buah nenas $(1,0,0)(0,1,0)^{12}$, buah apel $(0,1,1)(0,1,0)^{12}$ buah strawberi $(1,1,0)(1,1,0)^{12}$. Sedangkan model prakiraan penjualan jus jambu adalah $(1,0,0)(1,1$, $1)^{12}$, jus sirsak $(1,0,0)(0,1,1)^{12}$, jus nenas $(1,0,0)$ $(0,1,1)^{12}$, jus apel $(0,0,1)(1,1,0)^{12}$, dan jus strawberi $(1,0,1)(1,1,0)^{12}$.

Teknik prakiraan pasokan bahan baku buah segar dan prakiraan penjualan jus menggunakan teknik ARIMA memberikan keluaran nilai $e_{t}, \theta_{1}, \varnothing_{1}$ 
dan $\Phi_{1}$. Koefisien nilai $e_{t}$ untuk pasokan buah jambu adalah 0,0716; dan nilai $\Theta_{1}$ adalah 0,9559. Nilai $e_{t}$ adalah koefisien error, koefisien MA $\left(\Theta_{1}\right)$, koefisien $\operatorname{AR}\left(\varnothing_{1}\right)$, dan koefisien $\operatorname{SAR}\left(\Phi_{1}\right)$.

\section{Model Ketersediaan Bahan Baku Buah yang Layak di Produksi}

Manajemen persediaan bahan baku buah mempunyai peranan penting dalam keberlangsungan proses produksi jus buah. Sifat bahan baku buah segar yang mudah rusak dan bersifat musiman dan permintaan terhadap produk terus berlangsung sehingga penanganan persediaan bahan baku buah segar harus diperhatikan dengan baik.

Buah segar diproduksi menjadi jus dan sebagian lagi diproduksi menjadi puree. Puree adalah bubur buah yang dapat digunakan sebagai bahan baku jus pada saat jumlah buah segar tidak mencukupi untuk produksi jus. Penentuan jumlah produksi jus dan puree berdasarkan pada prakiraan jumlah pasokan buah segar $\left(\mathrm{FP}_{\mathrm{jt}}\right)$ dan prakiraan penjualan jus buah $\left(\mathrm{F}_{\mathrm{jt}}\right)$. Jika persediaan buah segar $\left(\mathrm{IS}_{\mathrm{jt}}\right)$ stok awal buah segar $\left(\mathrm{SAB}_{\mathrm{jt}}\right)$ dan jumlah stok sisa buah segar periode sebelumnya $\left(\mathrm{SSB}_{\mathrm{jt-1}}\right)$. Jumlah stok awal buah segar merupakan stok akhir buah segar periode sebelumnya $\left(S A B_{j t}=S S B_{j t-1}\right)$ dan prakiraan pasokan buah segar, $I S_{j t}=S A B_{j t}+F P_{j t}$.

Penentuan jumlah jus yang dihasilkan dari $\mathrm{kg}$ buah segar yaitu menggunakan faktor koreksi. Faktor koreksi adalah jumlah jumlah liter puree yang dihasilkan oleh 1 (satu) $\mathrm{kg}$ buah segar $\left(\mathrm{k}_{\mathrm{j}}\right)$ dan jumlah liter jus yang dihasilkan dari 1 (satu) $\mathrm{kg}$ buah $\operatorname{segar}\left(\mathrm{d}_{\mathrm{j}}\right)$.

Penentuan jumlah bahan baku buah segar yang layak digunakan $\left(\mathrm{IB}_{\mathrm{jt}}\right)$ dan laju kerusakan buah yang rusak $\left(\theta_{\mathrm{jt}}\right)$. Laju kerusakan buah menentukan jumlah buah yang rusak pada periode waktu tertentu. Jumlah buah yang layak digunakan adalah persediaan buah segar dikurangi dengan jumlah buah yang rusak, dengan persamaan adalah $I B_{j t}=I S_{j t}-\Sigma z j(t)$.

Penentuan jumlah produksi puree dan jus ditentukan oleh jumlah pasokan buah dan jumlah penjualan. Jika jumlah buah yang layak diproduksi kurang dari jumlah prakiraan penjualan jus buah $\left(d_{j} I B_{j t}<F_{j t}\right)$ maka akan diproduksi jus dari bahan baku buah sebesar $J S B_{j t}=I B_{j t} x d_{j}$ dan dari puree sebesar $J S P_{j t}=\left(F_{j t}-J S B_{j t}\right)+0,1 F_{j t}$. Sedangkan jika jumlah buah yang layak diproduksi sama dengan jumlah prakiraan penjualan jus buah $\left(d_{j} . I B_{j t}=F_{j t}\right)$ maka akan diproduksi jus dari buah segar sebanyak
$J S B_{j t}=I B_{j t} x d_{j}$ dan dari puree: $J S P_{j t}=0,1 \mathrm{Fjt}$. Namun pada saat jumlah buah yang layak diproduksi lebih dari jumlah prakiraan penjualan jus $\left(d_{j} \cdot I B_{j t}>\right.$ $F_{j t}$ ) maka akan diproduksi jus dan puree. Jumlah produksi jus dari buah segar sebanyak $J S B j=F_{j t}$ - $S A J_{j t}+0,1 F t$ dan akan diproduksi puree sebanyak $P R_{j}=\left(d_{j} . I B_{j t}-J S B_{j t}\right) x k_{j}$

Jumlah persediaan jus $\left(\mathrm{I}_{2 \mathrm{j} j}\right)$ adalah $I_{2 j t}=J S B_{j t}+$ $J S P_{j t}+S A J_{j t}$, sedangkan $S A J_{j t}=S S J_{j t-1 .}$ Jumlah stok awal jus $\left(S A J_{j t}\right)$ adalah stok akhir periode sebelumnya $\left(S S J_{j t-1}\right)$. Jumlah persediaan puree $\left(\mathrm{I}_{\mathrm{jj \textrm {j }}}\right)$ ditentukan oleh jumlah produksi dan jumlah persediaan awal periode $\left(I_{1 j t}=P R_{j t}+S A P_{j t}\right)$. Persediaan awal periode ditentukan oleh stok sisa periode sebelumnya atau $S A P_{j t}=S S P_{j t-1}$. Stok sisa buah segar $\left(\mathrm{SSB}_{\mathrm{jt}}\right)$ adalah persediaan buah segar yang layak digunakan $\left(\mathrm{IB}_{\mathrm{jt}}\right)$ dikurangi jumlah jus yang diproduksi dari buah segar $\left(\mathrm{JSB}_{\mathrm{jt}}\right)$ dan jumlah produksi puree $\left(\mathrm{PR}_{\mathrm{jt}}\right)$ atau SSBjt $=I B j t-\{$ (JSBjt $x$ vj $)+($ PRjt $x w j)$.Jumlah kg buah yang dibutuhkan untuk memproduksi 1 (satu) liter jus $\left(\mathrm{v}_{\mathrm{j}}\right)$ dan $\mathrm{kg}$ buah segar yang dibutuhkan untuk menghasilkan 1 (satu) $\mathrm{kg}$ puree $\left(\mathrm{w}_{\mathrm{j}}\right)$ adalah faktor koreksi jumlah satuan buah segar yang dibutuhkan. Penentuan jumlah $S S P_{j t}=\left\{I_{1 j t}-\left(J S P_{j t} x k_{j}\right)\right\}$ dan jumlah $S S J_{j t}=I_{2 j t}-F_{j t}$.

\section{Model Perencanaan Produksi Agregat}

Model perencanaan produksi agregat mempunyai tujuan untuk meminimumkan total biaya seluruh proses produksi baik produksi jus, produksi puree dan jumlah persediaan jus dan puree untuk memenuhi permintaan. Jika $i$ adalah tahapan proses, $j$ adalah jenis jus buah dan $t$ adalah periode (bulan) dengan variabel-variabel keputusan $\mathrm{X}_{i j t}, \mathrm{Y}_{i j t}$ dan $\mathrm{I}_{i j t}$. Variabel $\mathrm{X}_{i j t}$ adalah jumlah liter jus yang diproduksi dari buah segar dan puree pada jam kerja regular, $\mathrm{Y}_{i j t}$ jumlah liter jus yang diproduksi dari buah segar dan puree pada jam kerja lembur, $\mathrm{I}_{i j t}$ adalah jumlah persediaan jus dan puree. Jumlah persediaan jus adalah $\mathrm{I}_{2 \mathrm{j} t}$, dan jumlah persediaan puree adalah $\mathrm{I}_{1 \mathrm{jt}}$. Sedangkan $\mathrm{C}_{\mathrm{ij}}$, $\mathrm{A}_{\mathrm{ij}}, \mathrm{B}_{\mathrm{ij}}$ adalah biaya-biaya produksi jus dan puree pada jam kerja regular, jam kerja lembur dan biaya persediaan jus dan puree, maka fungsi tujuan dirumuskan sebagai berikut:

$$
\begin{gathered}
\text { MinimasiTC }=\sum_{\mathrm{i}=1}^{3} \sum_{\mathrm{t}=1}^{12}\left[\mathrm{C}_{\mathrm{i}} \mathrm{X}_{\mathrm{it}}+\mathrm{A}_{\mathrm{i}} \mathrm{Y}_{\mathrm{it}}+\mathrm{B}_{\mathrm{i}} \mathrm{I}_{\mathrm{it}}\right] \text { jambu }+ \\
{\left[\mathrm{C}_{\mathrm{i}} \mathrm{X}_{\mathrm{it}}+\mathrm{A}_{\mathrm{i}} \mathrm{Y}_{\mathrm{it}}+\mathrm{B}_{\mathrm{i}} \mathrm{I}_{\mathrm{it}}\right] \text { sirsak }+} \\
{\left[\mathrm{C}_{\mathrm{i}} \mathrm{X}_{\mathrm{it}}+\mathrm{A}_{\mathrm{i}} \mathrm{Y}_{\mathrm{it}}+\mathrm{B}_{\mathrm{i}} \mathrm{I}_{\mathrm{it}}\right] \text { nanas }+} \\
{\left[\mathrm{C}_{\mathrm{i}} \mathrm{X}_{\mathrm{it}}+\mathrm{A}_{\mathrm{i}} \mathrm{Y}_{\mathrm{it}}+\mathrm{B}_{\mathrm{i}} \mathrm{I}_{\mathrm{it}}\right] \text { apel }+} \\
\\
{\left[\mathrm{C}_{\mathrm{i}} \mathrm{X}_{\mathrm{it}}+\mathrm{A}_{\mathrm{i}} \mathrm{Y}_{\mathrm{it}}+\mathrm{B}_{\mathrm{i}} \mathrm{I}_{\mathrm{it}}\right] \text { strawberi }+\ldots \ldots . . .}
\end{gathered}
$$


$\mathrm{X}_{2 \mathrm{jt}}+\mathrm{X}_{3 \mathrm{jt}}+\mathrm{Y}_{2 \mathrm{jt}}+\mathrm{Y}_{3}+\mathrm{I}_{2 \mathrm{jt}-1}+\mathrm{I}_{3 \mathrm{jt}-1} \geq \mathrm{F}_{\mathrm{jt}}$

$w j \cdot X_{1 j t}+v j \cdot X_{2 j t}+w j \cdot Y_{1 j t}+v j \cdot Y_{2 j t}=I_{j t}$

$\mathrm{I}_{1 \mathrm{jt}-1}+\mathrm{X}_{1, \mathrm{j} . \mathrm{t}}+\mathrm{Y}_{1, \mathrm{j} \mathrm{t}} \leq \mathrm{K}$

$\mathrm{IJ}_{\mathrm{jt}-1}+\mathrm{X}_{2, \mathrm{j} . \mathrm{t}}+\mathrm{Y}_{2, \mathrm{j} . \mathrm{t}}+\mathrm{X}_{3 \mathrm{jt}}+\mathrm{Y}_{3 \mathrm{jt}} \leq \mathrm{G}$

$\mathrm{IJ}_{2 \mathrm{jt}} \geq 0,1 \mathrm{~F}_{\mathrm{jt}}$

$\mathrm{k}_{\mathrm{j}}\left(\mathrm{X}_{3 \mathrm{jt}}+\mathrm{X}_{3 \mathrm{jt}}\right) \leq \mathrm{I}_{\mathrm{jjt}-1}$

$\sum_{\mathrm{j}=1}^{\mathrm{S}}\left(\mathrm{X}_{1 \mathrm{jt}}+\mathrm{X}_{2 \mathrm{jt}}+\mathrm{X}_{3 \mathrm{jt}}\right) \leq \mathrm{Pt}$.

$\sum_{\mathrm{j}=1}^{\mathrm{S}}\left(\mathrm{Y}_{1 \mathrm{jt}}+\mathrm{Y}_{2 \mathrm{jt}}+\mathrm{Y}_{3 \mathrm{jt}}\right) \leq \mathrm{St}$

$\mathrm{I}_{1 \mathrm{jt}}-\mathrm{I}_{1, \mathrm{j}, \mathrm{t}-1}-\mathrm{X}_{1 \mathrm{j}, \mathrm{t}}-\mathrm{Y}_{1 \mathrm{j}, \mathrm{t}}+\mathrm{k}_{\mathrm{j}}\left(\mathrm{X}_{3 \mathrm{jt}}+\mathrm{Y}_{3 \mathrm{j \textrm {t }}}\right)=0$

$I_{2 j t}+I_{3 j \mathrm{t}}-X_{2, j, t}-Y_{2, j, t}+X_{3 j t}-Y_{3 j \mathrm{t}}=I_{2 j \mathrm{t}-1}+$

$\mathrm{I}_{3 \mathrm{jt}-1}-\mathrm{F}_{\mathrm{jt}}$

$\mathrm{X}_{\mathrm{ijt}}, \mathrm{Y}_{\mathrm{ijt}}, \mathrm{I}_{\mathrm{ijt}} \geq 0$

Di mana i adalah tahapan proses $1,2,3$, di mana $i=1$ adalah tahapan proses buah menjadi puree, $i=2$ adalah tahapan proses buah segarmenjadi jus, sedangkan $i=3$ adalah tahapan proses puree menjadi jus. Kapasitas gudang puree $(\mathrm{K})$ dan kapasitas gudang jus buah $(\mathrm{G})$, jumlah jam kerja reguler $\left(\mathrm{P}_{t}\right)$, dan jumlah jam kerja lembur $\left(\mathrm{S}_{t}\right)$.

\section{Model Jadwal Induk Produksi}

Model jadwal induk produksi akan memberikan gambaran jumlah produksi masing-masing produk dalam periode mingguan. Data yang dibutuhkan adalah jumlah pesanan yang telah dibukukan oleh perusahaan $(\mathrm{CO} /$ costumer order $)$, lead time, kebijakan perusahaan dalam sekali produksi akan memenuhi permintaan selama berapa periode dan jumlah awal persediaan $\left(\mathrm{I}_{0}\right)$. Jika $m$ adalah periode minggu, $j$ adalah jenis jus buah dan $n$ adalah jenis kemasan jus buah. Pemodelan jadwal induk produksi menggunakan penjadwalan induk produksi perspektif.

Pemodelan penjadwalan produksi selain memberikan gambaran jumlah produksi pada periode mingguan, juga akan memberikan informasi untuk menetapkan hari atau minggu untuk pengiriman pesanan atau permintaan produk yang baru (AP/Available to Promise). Dengan kata lain, Available to Promise akan memberikan informasi jumlah permintaan yang dapat di penuhi selama periode produksi selain dari jumlah permintaan yang telah dibukukan. Available to Promise telah memperhitungkan on hand inventory $(\mathrm{OH})$, permintaan atau order yang telah dipenuhi, jumlah produksi yang telah dijadwalkan (JIP-R). Jumlah persediaan produk yang ada pada periode- $m$ (on hand inventory, $\mathrm{OH}=\mathrm{I}_{j n \mathrm{~m}}$ ) adalah jumlah persediaan sebelumnya dan jumlah produksi yang harus selesai pada periode- $m$ dikurangi maksimum dari jumlah produksi mingguan $\left(\mathrm{GR}_{\mathrm{m}}\right)$ dan jumlah permintaan yang telah dibukukan $\left(\mathrm{CO}_{j n \mathrm{~m}}\right)$. Perumusan jumlah persediaan, Available to Promise dan jumlah produksi yang dijadwalkan pada minggu yang bersangkutan adalah sebagai berikut:

$$
\begin{aligned}
& \text { JIP-Rjnm }=\left[\max \left\{G R_{j n m}, C O_{j n m}\right\}+\right. \\
& \left.\max \left\{G R_{j n m+1}, C O_{j n m+1}\right\}\right]-I_{j n m-1} \ldots \ldots \ldots \ldots \ldots \ldots \ldots \ldots \ldots \ldots \ldots \ldots \ldots \ldots \ldots \ldots \ldots \ldots \\
& A P_{j n m}=I_{0}+J I P-R_{m}-\left(C O_{m}+C O_{m+1}\right) \ldots \ldots \ldots \ldots \ldots \ldots \ldots \\
& O H_{j n m}\left({ }_{j n} I_{m}\right)=I_{j n o}+J I P-R_{j n 1}-\operatorname{Max}\left\{G R_{j n m}, C O_{j n m}\right\} \ldots
\end{aligned}
$$

Jumlah produksi yang optimum yang dihasilkan dari pemodelan perencanaan produksi agregat akan dijadikan masukan pada jadwal induk produksi. Pemodelan jadwal induk produksi akan memberikan gambaran jumlah produksi masing-masing produk dalam periode mingguan.

\section{Hubungan antar Model}

Hasil keluaran dari model prakiraan jumlah pasokan bahan baku buah segar dan prakiraan jumlah penjualan jus akan dijadikan masukan untuk model perencanaan produksi agregat. Pemodelan jadwal induk produksi akan menggunakan keluaran dari model perencanaan produksi agregat. Jumlah pasokan bahan baku buah segar, jumlah ketersediaan bahan baku buah yang layak diproduksi, produk jadi, persediaan produk antara (puree) dan jumlah penjualan berperan sebagai sinkronisasi jumlah produksi jus. Keterkaitan antar variabel keputusan dalam model sangat bermanfaat dalam perumusan algoritma penyelesaian model. Gambar 2 akan memberikan gambaran proses integrasi dalam pengembangan model jadwal produksi jus berbahan baku buah segar.

\section{Perancangan Sistem Penunjang Keputusan}

Pendekatan secara sistem dalam pengambilan keputusan dikenal dengan istilah sistem penunjang keputusan adalah untuk memamparkan secara detil elemen-elemen sistem sehingga dapat membantu manajer dalam proses pengambilan keputusan (Eriyatno, 2003). Rancangan sistem penunjangn keputusan yang dihasilkan pada penelitian ini bernama Rp_JUS dan konfigurasinya dapat dilihat pada Gambar 3. Basis data terdiri dari data penjualan jus buah, data pasokan bahan baku buah segar, data 


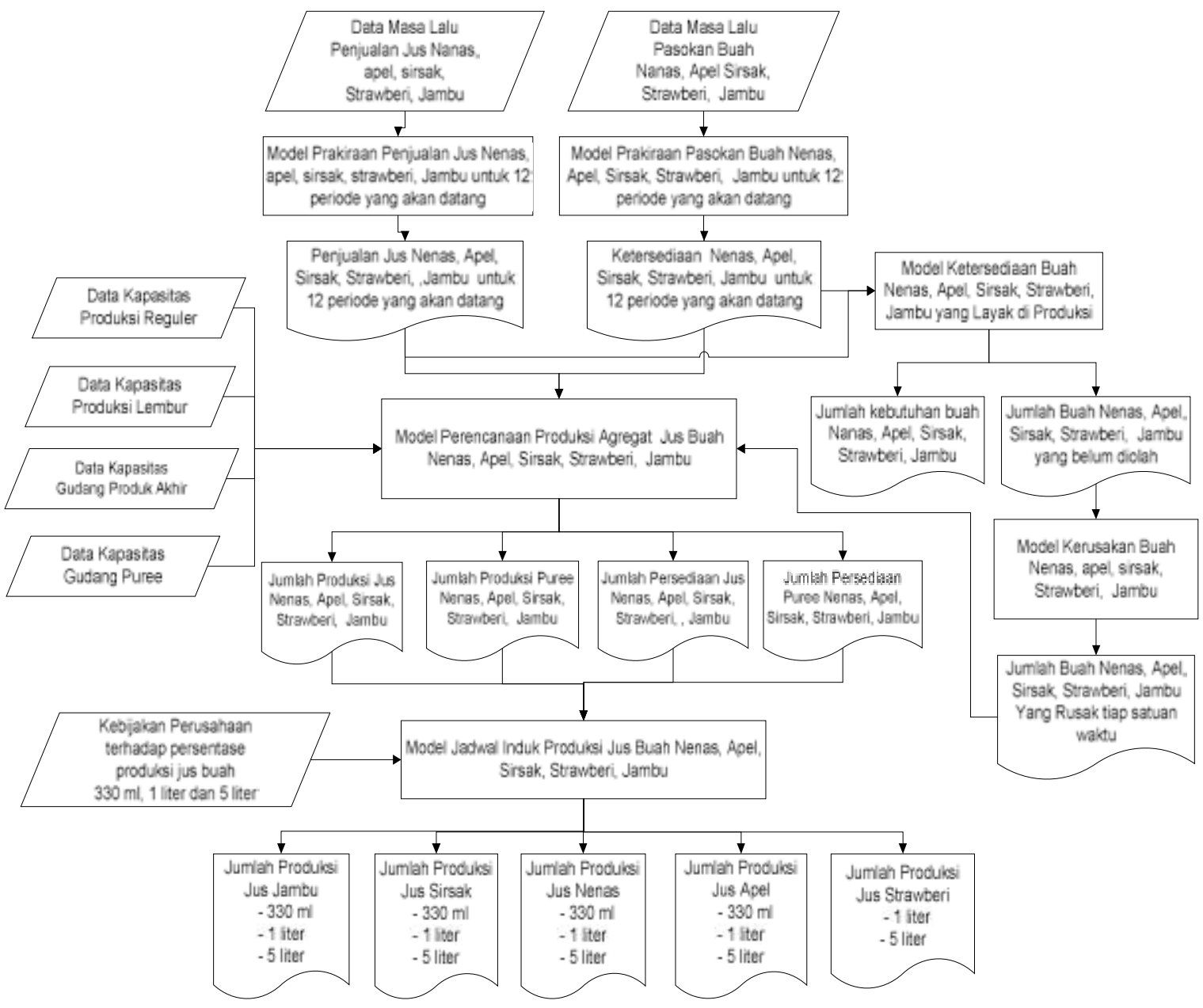

Gambar 2. Hubungan Antar Model Dalam Pengembangan Model Jadwal Produksi Jus Berbahan Baku Buah Segar

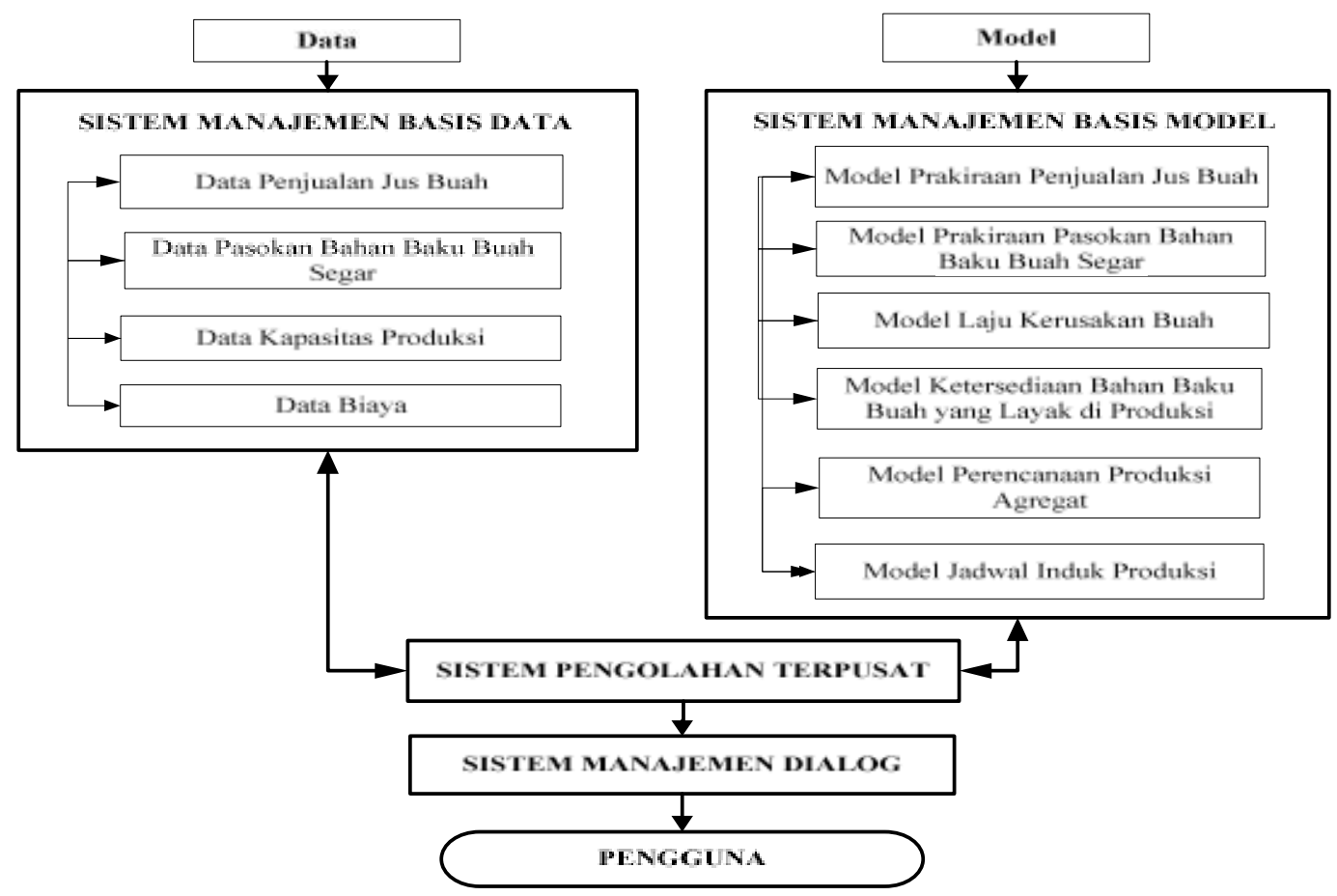

Gambar 3. Konfigurasi Sistem Penunjang Keputusan Rp_JUS 
kapasitas produksi dan data biaya. Sedangkan sistem manajemen basis model terdiri dari model prakiraan penjualan jus buah, model prakiraan pasokan bahan baku buah segar, model laju kerusakan buah, model ketersediaan bahan baku buah yang layak diproduksi, model perencanaan produksi agregat dan model jadwal induk produksi.

\section{Implementasi}

Program Rp_JUS dibangun oleh enam model dan masukan utama dari model-model model tersebut adalah prakiraan jumlah pasokan bahan baku buah dan prakiraan jumlah penjualan jus buah. Prakiraan pasokan bahan baku buah segar merupakan salah satu kendala yang harus diperhatikan untuk memenuhi tingkat permintaan konsumen. Hasil prakiraan pasokan bahan baku buah dan prakiraan jumlah penjualan jus dapat dilihat pada Tabel 1 .

Sifat bahan baku hasil pertanian yaitu mudah rusak (perishable) dan musiman, sehingga jumlah pasokan bahan baku buah segar jumlahnya tidak tetap. Pada saat panen raya jumlah pasokan akan berlimpah sehingga ketersediaan bahan baku akan berlimpah dan jumlah produksi akan meningkat. Pada kondisi yang lain jumlah pasokan terbatas bahkan tidak ada ketersediaan pasokan bahan baku buah segar. Untuk mengatasi hal tersebut, proses pembuatan jus buah tidak hanya menggunakan bahan baku buah segar tetapi menggunakan bahan baku puree agar proses produksi tetap berjalan.
Laju kerusakan buah menunjukkan bahwa laju kerusakan buah jambu, sirsak, nenas, apel dan strawberi mengikuti distribusi eksponensial. Laju kerusakan buah mengikuti distribusi eksponensial karena jumlah kerusakan buah semakin meningkat seiring dengan bertambahnya waktu. Proses kerusakan buah dipengaruhi oleh produksi etilen yang meningkat sehingga merusak susunan protein pada buah sehingga kerusakan buah semakin meningkat tajam. Nilai tengah laju kerusakan masing-masing buah adalah 0,059 untuk jambu; 0,112 untuk sirsak; 0,043 untuk nenas; 0,032 untuk apel; dan 0,251 untuk strawberi.

Penentuan jumlah ketersediaan bahan baku buah yang layak diproduksi adalah dengan memperhitungkan laju kerusakan buah. Hasil perhitungan jumlah ketersediaan bahan baku buah yang layak diproduksi menjadi jus buah dapat dilihat pada Tabel 2.

Analisis optimasi perencanaan produksi agregat dapat dilihat pada Tabel 3 yang bertujuan untuk mendapatkan biaya produksi yang minimum. Hasil optimasi perencanaan produksi untuk jangka waktu 12 bulan adalah jumlah produksi puree sebanyak $462.288,48 \mathrm{~kg}(69 \%)$ pada jam kerja reguler dan 207.692,30 kg (31\%) pada jam kerja lembur. Sedangkan total produksi jus dari buah segar sebanyak 3.254.964,40 liter $(86,16 \%)$ produksi jus dari puree sebanyak 522.743,57 liter (13,85\%).

Tabel 1. Prakiraan Penjualan Jus Buah dan Pasokan Bahan Baku Buah

\begin{tabular}{|c|c|c|c|c|c|c|c|c|c|c|}
\hline \multirow[b]{2}{*}{ Bulan } & \multicolumn{2}{|c|}{ Jambu } & \multicolumn{2}{|c|}{ Sirsak } & \multicolumn{2}{|c|}{ Nenas } & \multicolumn{2}{|c|}{ Apel } & \multicolumn{2}{|c|}{ Strawberi } \\
\hline & $\begin{array}{c}\text { Penjualan } \\
\text { (Liter) }\end{array}$ & $\begin{array}{c}\text { Pasokan } \\
(\mathrm{Kg})\end{array}$ & $\begin{array}{l}\text { Penjualan } \\
\text { (Liter) }\end{array}$ & $\begin{array}{c}\text { Pasokan } \\
\text { (Kg) }\end{array}$ & $\begin{array}{c}\text { Penjualan } \\
\text { (Liter) }\end{array}$ & $\begin{array}{c}\text { Pasokan } \\
(\mathrm{Kg})\end{array}$ & $\begin{array}{l}\text { Penjualan } \\
\text { (Liter) }\end{array}$ & $\begin{array}{c}\text { Pasokan } \\
(\mathrm{Kg})\end{array}$ & $\begin{array}{c}\text { Penjualan } \\
\text { (Liter) }\end{array}$ & $\begin{array}{c}\text { Pasokan } \\
\text { (Kg) }\end{array}$ \\
\hline 1 & $116.233,00$ & $79.715,00$ & $52.641,90$ & $9.754,20$ & $79.169,90$ & 320,40 & $40.383,10$ & $6.329,40$ & $33.579,70$ & $5.258,74$ \\
\hline 2 & $120.762,00$ & $42.115,00$ & $55.138,10$ & $17.853,00$ & $82.907,50$ & $12.199,10$ & $42.344,50$ & $6.745,40$ & $35.269,90$ & $4.547,23$ \\
\hline 3 & $119.836,00$ & $142.480,00$ & $52.542,30$ & $9.173,00$ & $78.781,60$ & $13.304,60$ & $42.402,20$ & $17.785,40$ & $35.231,50$ & $3.008,85$ \\
\hline 4 & $109.664,00$ & $57.363,00$ & $50.716,20$ & $7.093,00$ & $75.838,00$ & 59,80 & $38.686,00$ & $12.729,40$ & $32.072,50$ & $4.777,43$ \\
\hline 5 & $119.145,00$ & $151.691,00$ & $55.451,20$ & $18.237,00$ & $83.035,90$ & $16.482,20$ & $42.190,10$ & $6.649,40$ & $35.127,70$ & $4.005,10$ \\
\hline 6 & $118.116,00$ & $183.435,00$ & $55.734,70$ & $23.325,00$ & $83.350,10$ & 19,50 & $41.635,40$ & $14.329,40$ & $34.662,50$ & $5.019,34$ \\
\hline
\end{tabular}

Tabel 2. Jumlah Ketersediaan Bahan Baku Buah yang Layak Diproduksi (Kg)

\begin{tabular}{lrrrrrr}
\hline Periode (Bulan) & \multicolumn{1}{c}{$\mathbf{1}$} & \multicolumn{1}{c}{$\mathbf{2}$} & \multicolumn{1}{c}{$\mathbf{3}$} & \multicolumn{1}{c}{$\mathbf{4}$} & \multicolumn{1}{c}{$\mathbf{5}$} & \multicolumn{1}{c}{ ( } \\
\hline Jambu & $63.237,85$ & $33.410,01$ & $113.028,96$ & $45.505,68$ & $120.336,20$ & $145.518,51$ \\
Sirsak & $4.330,86$ & $7.926,73$ & $4.072,81$ & $3.149,29$ & $8.097,23$ & $10.356,30$ \\
Nenas & 306,72 & $11.678,20$ & $12.736,49$ & 57,25 & $15.778,41$ & 18,67 \\
Apel & $6.124,96$ & $6.527,52$ & $17.210,93$ & $12.318,24$ & $6.434,62$ & $13.866,56$ \\
Strawberi & $5.908,19$ & $5.108,82$ & $3.380,45$ & $5.367,44$ & $4.499,73$ & $5.639,23$ \\
\hline
\end{tabular}


Tabel 3. Hasil Optimasi Perencanaan Produksi pada Periode 1 dan 2

\begin{tabular}{|c|c|c|c|c|c|c|c|c|c|}
\hline \multirow{4}{*}{$\begin{array}{l}\text { Periode } \\
\text { (Bulan) }\end{array}$} & \multirow{4}{*}{ Jenis } & \multicolumn{6}{|c|}{ Produksi } & \multirow{2}{*}{\multicolumn{2}{|c|}{ Persediaan }} \\
\hline & & \multicolumn{3}{|c|}{ Jam Kerja Reguler } & \multicolumn{3}{|c|}{ Jam Kerja Lembur } & & \\
\hline & & \multirow{2}{*}{$\begin{array}{c}\text { Puree } \\
\text { (Kg) }\end{array}$} & \multicolumn{2}{|c|}{ Jus (Liter) } & \multirow{2}{*}{$\begin{array}{c}\text { Puree } \\
\text { (Kg) }\end{array}$} & \multicolumn{2}{|c|}{ Jus (liter) } & \multirow{2}{*}{$\begin{array}{c}\text { Puree } \\
\text { (Kg) }\end{array}$} & \multirow[b]{2}{*}{ Jus (Liter) } \\
\hline & & & $\begin{array}{l}\text { Dari Buah } \\
\text { Segar }\end{array}$ & $\begin{array}{c}\text { Dari } \\
\text { Puree }\end{array}$ & & $\begin{array}{l}\text { Dari Buah } \\
\text { Segar }\end{array}$ & $\begin{array}{c}\text { Dari } \\
\text { Puree }\end{array}$ & & \\
\hline \multirow[t]{5}{*}{1} & Jambu & $20.813,96$ & $121.170,00$ & - & - & - & - & $21.813,96$ & $16.937,04$ \\
\hline & Sirsak & - & $31.019,70$ & - & - & $33.620,00$ & - & $5.000,00$ & $16.998,70$ \\
\hline & Nenas & 932,20 & $82.086,89$ & - & - & - & - & $17.932,20$ & $7.916,99$ \\
\hline & Apel & - & $38.043,23$ & $1.878,18$ & - & - & - & $2.222,03$ & $4.038,31$ \\
\hline & Strawberi & - & $38.117,35$ & - & - & - & - & $2.500,00$ & $9.537,66$ \\
\hline \multirow[t]{5}{*}{2} & Jambu & - & $106.912,00$ & $35.071,96$ & - & - & - & $12.835,53$ & $38.159,04$ \\
\hline & Sirsak & $3.957,63$ & $50.438,99$ & - & - & - & - & $8.957,63$ & $12.299,69$ \\
\hline & Nenas & - & $86.864,67$ & - & $1.588,32$ & - & - & $19.520,51$ & $11.874,66$ \\
\hline & Apel & - & $40.543,60$ & $3.486,67$ & - & - & - & $1.706,00$ & $6.724,58$ \\
\hline & Strawberi & - & $32.960,00$ & - & - & - & - & $2.500,00$ & $7.227,76$ \\
\hline
\end{tabular}

Produksi jus jambu selama 12 periode (bulan) perencanaan memproduksi jus jambu dari buah segar dan memproduksi puree dilakukan pada jam kerja regular. Produksi jus pada periode 2,8 dan 9 menggunakan bahan baku buah segar dan bahan baku puree. Hanya pada periode 7 dan 12 menggunakan jam kerja lembur yaitu untuk memproduksi puree sebesar $69.989,02 \mathrm{~kg}$ pada periode 7 dan 20.628,93 kg pada periode 12 . Hal ini disebabkan karena jumlah pasokan buah jambu mencukupi jumlah permintaan jus jambu.

Pada periode 11 dan 12, pasokan bahan baku sirsak diproduksi menjadi puree. Sedangkan pada periode yang lain pasokan bahan baku diproduksi menjadi jus sirsak dan puree. Produksi jus sirsak dilakukan pada jam kerja reguler, hanya pada periode 1 menggunakan jam kerja lembur yaitu memproduksi jus sirsak dari bahan baku buah segar sebesar 33.620,00 liter.

Pasokan bahan baku nenas hanya diproduksi menjadi jus nenas pada periode $1,2,5$, dan 12 . Sedangkan pada periode $4,6,7,8$ dan periode 9 produksi jus nenas menggunakan bahan baku buah segar dan bahan baku puree. Hal ini karena jumlah pasokan bahan baku buah segar tidak mencukupi permintaan jus nenas. Jam kerja lembur digunakan pada periode 2, 3, 5, 10 dan 12 untuk memproduksi puree.

Produksi jus apel dan puree secara keseluruhan dilakukan pada jam kerja regular. Pada periode 1, 2 dan periode 7 produksi jus apel menggunakan bahan baku buah segar dan bahan baku puree. Hal ini karena jumlah pasokan bahan baku buah apel tidak mencukupi untuk produksi jus apel, sehingga perlu menggunakan bahan baku puree agar permintaan konsumen terpenuhi.
Produksi jus strawberi selama 2 periode yaitu pada periode 3 dan periode 5 memproduksi jus menggunakan bahan baku buah segar dan puree. Hal ini karena jumlah pasokan buah strawberi tidak mencukupi memproduksi sejumlah permintaan, sehingga kekurangan produksi menggunakan bahan baku puree. Sedangkan pada periode $6,8,9$, 10 dan 12 pasokan bahan baku strawberi diproduksi menjadi puree dan jus strawberi. Proses produksi jus strawberi dan puree strawberi dilakukan pada jam kerja regular.

Persentase produksi jus jambu, jus sirsak, jus nenas, jus apel dan jus strawberi adalah sebesar $35,47 \% ; 16,70 \% ; 25,11 \% ; 12,42 \%$ dan $10,30 \%$ dari total produksi jus. Penggunaan jam kerja dalam produksi jus adalah $99,18 \%$ produksi jus dilakukan pada jam kerja regular, sedangkan $0,82 \%$ dilakukan pada jam kerja lembur.

Produksi jus dan produksi puree pada jam kerja lembur hanya sebesar 1 persen dari total produksi puree dan sebesar 3 persen dari total produksi jus buah secara keseluruhan. Secara umum hasil optimasi perencanaan produksi agregat terhadap produksi jus buah maupun produksi puree dapat dilakukan pada jam kerja reguler. Hal ini berarti kapasitas produksi perusahaan mampu memenuhi permintaan pasar. Hal ini sangat diperlukan untuk menjaga kepercayaan konsumen terhadap produk jus buah, karena apabila perusahaan tidak mampu memenuhi permintaan konsumen maka kehilangan kepercayaan konsumen akan menyebabkan perusahaan kehilangan penjualan.

Biaya perencanaan produksi dapat dihitung setelah dilakukan perhitungan perencanaan produksi agregat. Biaya-biaya yang dihitung adalah 
Tabel 4. Hasil Jadwal Induk Produksi

\begin{tabular}{lllrrrrr}
\hline & & Minggu & $\mathbf{1}$ & \multicolumn{1}{c}{$\mathbf{2}$} & \multicolumn{1}{c}{$\mathbf{3}$} & \multicolumn{1}{c}{$\mathbf{4}$} & $\mathbf{5}$ \\
\cline { 2 - 8 } & \multirow{2}{*}{$330 \mathrm{ml}$} & JIP-R & $3.658,50$ & $8.458,50$ & $6.058,50$ & $6.058,50$ & $3.711,80$ \\
& & AP & $3.733,84$ & $5.218,36$ & $1.978,22$ & $3.387,40$ & $4.683,96$ \\
\cline { 2 - 8 } Jus Jambu & \multirow{2}{*}{1 liter } & JIP-R & $9.146,25$ & $21.146,25$ & $15.146,25$ & $15.146,25$ & $9.279,50$ \\
& & AP & $9.334,60$ & $13.045,90$ & $4.945,55$ & $8.468,50$ & $11.709,90$ \\
\cline { 2 - 8 } & 5 Jiter & JIP-R & $5.487,75$ & $12.687,75$ & $9.087,75$ & $9.087,75$ & $5.567,70$ \\
& & AP & $5.600,76$ & $7.827,54$ & $2.967,33$ & $5.081,10$ & $7.025,94$ \\
\hline
\end{tabular}

biaya produksi jus buah dari bahan baku buah segar, biaya produksi jus buah dari bahan baku puree, biaya produksi buah segar menjadi puree pada jam kerja regular maupun jam kerja lembur. Selain itu, diperhitungkan juga biaya persediaan dalam bentuk puree dan jus buah.

Jadwal induk produksi jus adalah upaya untuk merencanakan jumlah produksi yang harus dilakukan pada periode mingguan untuk menjagakelancaran produksi. Tabel 4 merupakan hasil jadwal induk produksi jus.

Jadwal induk produksi penting dalam menghasilkan produk yang kontinyu. Model memfasilitasi jumlah kemampuan produksi dan jumlah permintaan yang harus dipenuhi. Model yang dikembangkan menggunakan penjadwalan produksi berbasiskan jumlah permintaan yang telah dibukukan sehingga jumlah yang diproduksi sesuai dengan kebutuhan. Hasil optimasi jadwal induk produksi menghasilkan setiap minggu produksi jus baik dari buah segar maupun dari bahan baku puree.

\section{SIMPULAN}

Model yang telah berhasil dibangun terdiri dari prakiraan pasokan bahan baku buah segar, prakiraan jumlah penjualan jus buah, laju kerusakan, ketersediaan bahan baku buah yang layak diproduksi, perencanaan produksi agregat dan jadwal produksi induk. Keseluruhan dirangkai menjadi sebuah sistem penunjang keputusan dengan nama Rp_JUS. Rp_JUS telah diterapkan pada sebuah agro industri untuk menghasilkan rencana produksi agregat. Rp_JUS menghasilkan rencana produksi jus dan puree yang optimal dengan total biaya Rp 14.703.113.000,00.

\section{DAFTAR PUSTAKA}

Asmundsson, J. Uzsoy R., and Rardin, R.L, 2002. An alternative Modeling Framework for Aggregate Production Planning. Laboratory for Extended Enterprises at Purdue, scholl of Industrial Engineering. Grissom Hall. Purdue University, West Lafayette.

Eriyatno. 2003. Ilmu Sistem Meningkatkan Mutu dan Efektifitas Manajemen. IPB Press, Bogor.

Filho, A.T.A., Souza, F.M.C., and Almeida AT., 2006. A Multicriteria Decision Model for Aggregate Planning Based On The Manufacturing Strategy. Third International Conference on Production ResearcThird Research-Americas' Region.

Pahl, J., Vob, S., and Wooddruff, D.L., 2008. Production Planning with Deterioration Constrains: A Survey. $19^{\text {th }}$ International Conference on Production Research.

Manetsch, T.J. and Park, G.L., 1979. System Analysis and Simulation with Application to Economic and Social System. Michigan State University, USA.

Techawiboonwong A. and Yenradee P., 2002. Aggregate Production Planning Using Spreadsheet Solver: Model and Case Study. SicenceAsia 28: 291-300.

Thierauf, R.J. and Klekamp., 1975. Decision Making Through Operation Research. John Wiley and Sons Inc., New York.

Tsobune H, Muramatsu R., and Soshirodas M., 1986. A Production Model for Agricultural Processing Products. International Journal of Production Research 24: 799-809. 